\title{
Perbedaan Jenis Pertanyaan Netral dengan Jenis Pertanyaan Misleading Terhadap Munculnya False Memory pada Anak Usia Prasekolah
}

\section{(Differences Types of Neutral Questions with Misleading Question Types on the Emergence of False Memory in Preschoolers)}

\author{
M. APRIANDI ${ }^{1}$, CHARYNA AYU R, ANDI TENRI FARADIBA
}

Fakultas Psikologi, Universitas Pancasila

Email: andiapri8@gmail.com ${ }^{1}$

\section{Diterima 1 Mei 2017, Disetujui 22 Agustus 2017}

\begin{abstract}
Abstrak: False memory mengacu pada pengalaman berpikir saat kita mengingat sesuatu yang sebenarnya tidak benar-benar terjadi. Masalah utama dari false memory adalah kemungkinan memori tersebut dapat membuat seseorang mudah diarahkan ke informasi yang keliru. Penelitian ini menguji perbedaan antara dua jenis pertanyaan pada false memory anak prasekolah. Penelitian ini menggunakan desain eksperimen dengan 76 peserta anak prasekolah (53,9\% laki-laki dan 46,1\% perempuan, usia 5-6 tahun) yang terbagi dalam dua kelompok eksperimen. Kelompok pertama diberi pertanyaan netral, sedangkan kelompok kedua diberi pertanyaan misleading. Dalam percobaan ini, peserta diinstruksikan untuk menonton video, kemudian diberikan pertanyaan rekognisi. Pada tes rekognisi, partisipan diperlihatkan beberapa gambar dan diberi pertanyaan mengenai sebuah event. Hasilnya menunjukkan bahwa ada perbedaan yang signifikan antara dua tipe pertanyaan $(0.04<0.05)$ dengan nilai Chi-Square sebesar 11,647 . Berdasarkan hasil tersebut, dapat diartikan bahwa pertanyaan misleading dapat meningkatkan false memory daripada pertanyaan netral.
\end{abstract}

Kata kunci: false memory; pertanyaan misleading; pertanyaan netral; tes rekognisi; anak usia prasekolah

Abstract: False memory refers to the experience of thinking when we remember something that actually did not really happen. The major problem with false memory is the possibility to make someone may easily be led through misinformation. The current research assessed the difference between two types of question on preschoolers' false memory. This study used an experimental design with 76 participants of preschoolers $(53.9 \%$ male and $46.1 \%$ female, 5-6 years old) who divided into two experimental groups. First group was given a neutral question, while the second group was given a misleading question. In this experiment, the participants were instructed to watch a video, then, one recognition test will be held immediately. In recognition test, participants were showed some pictures and questions about one event. The chi-square analysis shows that there is a significant difference between two types of question $(0.04<0.05)$ the value of Chi-Square was 11.647. Based on these results, it implies that misleading questions might raise more false memory than neutral questions.

Keywords: false memory; misleading question; neutral question; recognition test; preschoolers

\section{PENDAHULUAN}

Newman dan Lindsay (2009)
menggunakan istilah false memory dalam
menjelaskan berbagai jenis kesalahan memori
mulai dari daftar kosa kata, laporan detail suatu
kejadian, hingga ingatan yang keliru pada
peristiwa dramatis dalam kehidupan sehari-hari.
Loftus (dalam Nadel, 2003) mendefiniskan false

memory sebagai pengalaman berpikir ketika mengingat sesuatu dari masa lalu yang tidak benar-benar terjadi. Seseorang yang mengalami false memory akan mengalami kesulitan untuk menngingat, sehingga ia meyakini suatu perisitiwa/informasi yang tidak pernah ia alami/terima.

Penelitian yang dilakukan oleh Loftus dan Palmer (1974), menunjukkan hasil bahwa 
pertanyaan-pertanyaan yang diarahkan secara sengaja (leading question) dapat membentuk kekeliruan pada ingatan (false memory). Dalam penelitian tersebut, para partisipan ditugaskan untuk menyaksikan sebuah video klip yang menayangkan sebuah kecelakaan mobil, dan selanjutnya mereka diminta untuk memberikan estimasi kecepatan mobil-mobil dalam video klip tersebut. Variabel independen yang digunakan dalam penelitian tersebut adalah suatu kata khusus dalam pertanyaan saat para partisipan ditanyai estimasi kecepatan mobil-mobil yang terdapat dalam video klip. Dalam pertanyaan "seberapa cepat mobil-mobil itu melaju ketika mereka ... satu sama lain?" Loftus dan Palmer (1974) menggunakan variasi kata untuk mengisi kata yang kosong dalam kalimat tersebut dengan hit (bertabrakan), smashed (bertabrakan hingga ringsek), collied (bersinggungan), bumped (berbenturan), atau contacted (sekedar bersentuhan). Hasilnya, kata smashed menghasilkan estimasi kecepatan tertinggi sedangkan kata contacted menghasilkan estimasi kecepatan terendah. Hasil estimasi kecepatan mobil tersebut bukanlah disebabkan oleh kecepatan mobil itu sendiri, melainkan diakibatkan oleh pemilihan kata yang digunakan dalam pertanyaan yang menimbulkan kekeliruan ingatan yang disebut sebagai false memory.

Stewart dan Cash (2012), menyatakan bahwa berdasarkan kendali atau kontrol pewawancara terhadap jawaban yang ingin didapat, jenis pertanyaan dibagi menjadi dua, yaitu: netral dan leading. Pertanyaan netral merupakan pernyataan yang memungkinkan partisipan untuk menjawab tanpa arah atau tekanan dari pewawancara. Sedangkan pertanyaan leading merupakan pertanyaan yang menyarankan jawaban yang diharapkan atau diinginkan karena pewawancara mengarahkan partisipan terhadap jawaban tertentu. Pertanyaan leading yang mengarahkan seseorang pada jawaban yang salah disebut pertanyaan misleading (Bruck \& Ceci, 1999).

Penelitian yang dilakukan oleh Bruck, Ceci, Francoeur, dan Barr (1995), membuktikan bahwa false memory bisa muncul akibat penggunaan jenis pertanyaan yang berbeda secara berulang-ulang. Anak-anak usia lima tahun yang merupakan responden dari penelitian ini melakukan kunjungan ke dokter untuk mendapatkan suntik vaksinasi. Satu tahun kemudian mereka diwawancarai sebanyak empat kali terkait rincian peristiwa yang penting dalam kunjungan medis tersebut. Pada setiap sesi wawancara, anak-anak yang tidak diberikan sugesti dan diwawancarai dengan jenis pertanyaan netral secara berulang-ulang memberikan laporan yang lebih akurat dengan persentase kesalahan tertinggi $10 \%$. Sementara anak-anak yang diberi sugesti pada informasi yang salah secara berulang-ulang dan diwawancarai dengan jenis pertanyaan misleading memberikan laporan yang tidak akurat. Persentase kesalahan jawaban pada kelompok misleading berkisar $60 \%-40 \%$ pada setiap sesi wawancara.

Penelitian-penelitian tersebut memiliki kesamaan, yaitu pada teknik retrieval menggunakan recall. Recall dilakukan dengan cara memberi partisipan pertanyaan dengan jenis yang berbeda-beda. Strenberg (2011), menjelaskan proses pengambilan informasi kembali (retrieval process) terdiri dari dua jenis teknik, yaitu recall (mengingat) dan rekognisi (mengenali). Menurut teori perkembangan kognitif Piaget (dalam Santrock, 2010), anakanak usia lima tahun atau prasekolah berada pada tahap pra-operational. Pada tahap tersebut pemahaman anak terhadap dunia sekitarnya terjadi melalui hal-hal yang bersifat konkrit atau nyata, seperti kata-kata, gambar-gambar atau simbol. Peneliti mengasumsikan bahwa berdasarkan teori perkembangan kognitif Piaget (dalam Santrock, 2010), kemungkinan anak mengalami false memory ketika diberikan pertanyaan dalam bentuk misleading, sehingga persentase kesalahan jawaban pada kelompok anak yang diberikan pertanyaan misleading mencapai 60\%-40\% (Bruck, Ceci, Francoeur, dan Barr, 1995).

Anak-anak masih banyak yang mengalami kasus kekerasan seksual di Indonesia. Hasil survei Komisi Perlindungan Anak Indonesia (KPAI), selama dalam kurun waktu 6 tahun, dari tahun 2011 hingga tahun 2016, terdapat 7.698 
kasus anak berhadapan dengan hukum, $1.965 \mathrm{di}$ antaranya adalah kasus anak sebagai korban kekerasan seksual (KPAI, 2016). Penulis mendapatkan informasi yang serupa dengan datadata sebelumnya dari hasil wawancara pada tanggal 12 April 2017 kepada seorang narasumber di Komnas Perlindungan Anak. Ivana, salah satu konselor Komnas Perlindungan Anak menjelaskan, bahwa saat ini kekerasan seksual terhadap anak cenderung meningkat. Sisi positifnya adalah para korban atau orang tua korban lebih berani untuk melaporkan kasus kekerasan seksual yang dialami oleh anak mereka ke pihak kepolisian maupun ke Komnas Perlindungan Anak.

Setiap laporan kekerasan seksual yang masuk ke Komnas Perlindungan Anak, akan dilakukan proses penggalian informasi kepada para anak-anak korban kekerasan seksual. Penggalian informasi dilakukan untuk membuktikan apakah anak tersebut benar mengalami kekerasan seksual atau tidak. Proses penggalian informasi tesebut tidaklah mudah khususnya untuk anak-anak yang berusia 2 sampai 6 tahun. Anak yang berusia 2 sampai 6 tahun disebut sebagai anak usia prasekolah (Santrock, 2010).

Penggalian informasi pada anak usia prasekolah yang mengalami kekerasan seksual di Komnas Perlindungan Anak dilakukan oleh konselor dengan metode in-depth interview. Pada proses in-depth interview anak-anak diberikan pertanyaan yang mengarahkan pada hal-hal atau kejadian yang dialami oleh anak. Keterangan atau informasi yang disampaikan oleh anak selama proses in-depth interview dianggap cukup akurat karena anak-anak tidak pernah berbohong atas apa yang ia alami. Keterangan anak yang cukup akurat bisa dijadikan salah satu dasar dalam persidangan kasus si anak. Namun melihat dari hasil penelitian mengenai akurasi keterangan pada anak usia lima tahun yang dilakukan Bruck, Ceci, Francoeur, dan Barr (1995), ingatan anak mudah dikelirukan dengan penggunaan jenis pertanyaan yang berbeda.

Maka dari itu peneliti tertarik untuk meneliti apakah pemberian jenis pertanyaan yang berbeda dapat menimbulkan false memory pada anak usia prasekolah. Peneliti juga tertarik untuk meneliti permasalahan ini karena di awal telah disebutkan bahwa jumlah kasus kekerasan seksual yang terjadi pada anak usia prasekolah di Indonesia cenderung meningkat dan masih jarang pembahasan terkait false memory khususnya pada anak-anak di Indonesia. Selain itu, penelitian ini dapat memberikan bukti apakah ingatan anak-anak khususnya usia prasekolah akurat.

False Memory. Newman dan Lindsay (2009) mendefiniskan istilah false memory sebagai berbagai jenis kesalahan memori mulai dari kosa kata yang salah diingat, laporan yang salah dalam suatu kejadian, hingga ingatan yang keliru pada peristiwa penting dalam kehidupan seharihari. Bruck dan Ceci (1999), membuktikan bahwa ingatan anak usia 3-4 tahun lebih mudah mengalami distorsi yang memicu munculnya false memory. Distorsi pada memori manusia sendiri memiliki bentuk yang dapat menimbulkan false memory. Schacter (dalam Smith \& Kosslyn, 2014), menyatakan salah satu faktor munculnya distorsi yang mengakibatkan kesalahan pada memori adalah sugesti.

Sugesti merupakan penanaman informasi ke dalam memori seseorang. Seseorang akan mengalami distorsi akibat sugesti apabila informasi yang ditanamkan merupakan informasi yang salah (tidak sesuai kenyataan), dan seseorang akan mengalami kesulitan mengingat. Sehingga orang tersebut akan kesulitan membedakan mana informasi/kejadian yang asli (benar) dengan informasi/kejadian yang palsu (salah). Salah satu cara untuk menanamkan sugesti pada seseorang adalah dengan memberikan pertanyaan yang mengarahkan pada informasi yang salah.

Penggalian informasi dengan memberikan pertanyaan termasuk dalam proses retrieval. Bentuk pertanyaan yang berbeda, akan mengeluarkan bentuk jawaban yang berbeda pula. Menurut Stewart dan Cash (2012), berdasarkan kendali atau kontrol pewawancara terhadap jawaban yang ingin didapat, jenis pertanyaan dibagi menjadi dua, yaitu pertanyaan netral dan pertanyaan leading. Pertanyaan netral merupakan pernyataan yang memungkinkan 
partisipan untuk menuntaskan jawaban tanpa arah atau tekanan dari pewawancara. Misalnya, dalam pertanyaan netral yang diwawancarai menentukan panjang, detail, dan sifat jawaban. Pertanyaan leading merupakan pertanyaan yang mengarahkan partisipan ke jawaban yang spesifik sesuai keinginan pewawancara. Pertanyaan leading yang mengarahkan partisipan pada informasi atau jawaban yang salah disebut pertanyaan misleading (Bruck \& Ceci, 1999).

Selain menghasilkan jawaban yang berbeda, penggunaan jenis pertanyaan netral atau misleading juga memiliki dampak yang berbeda pada memori seseorang. Sebelumnya dijelaskan bahwa penggunaan pertanyaan yang mengarahkan pada informasi salah (misleading) merupakan cara mensugesti seseorang. Sugesti yang diberikan dari pertanyaan misleading akan mendistorsi memori seseorang. Distorsi yang terjadi pada memori seseorang mengakibatkan false memory. Loftus (2003), menyatakan bahwa pertanyaan misleading merupakan salah satu jalan untuk mendistorsi memori sehingga muncul false memory.

Secara aspek kognitif menurut Papalia dan Feldman (2014), selama masa perkembangan, anak usia prasekolah mengalami peningkatan kemampuan pengolahan informasi dan memori. Kemampuan anak dalam fokus perhatian dan kecepatan pengolahan informasi terus meningkat seiring bertambahnya usia mereka. Anak usia prasekolah juga mulai membentuk memori jangka panjang mereka. Meskipun secara kemampuan memori meningkat, ingatan anak usia prasekolah tidak sebaik ingatan orang yang lebih tua. Anak usia prasekolah lebih fokus pada detail informasi dari sebuah peristiwa, sementara orang dewasa umumnya berfokus pada intisari dari sebuah peristiwa. Pada proses retrieval kemampuan anak usia prasekolah sama seperti kelompok usia lainnya (orang dewasa atau yang lebih tua). Anak usia prasekolah memiliki kemapuan yang lebih baik saat merekognisi (mengenali) dibanding recall (mengingat) (Sophian, Wood, \& Vong, 1995).

Berdasarkan penjelasan yang sudah dipaparkan, maka masalah penelitian ini adalah apakah terdapat perbedaan antara pemberian jenis pertanyaan netral dengann jenis pertanyaan misleading terhadap munculnya false memory pada anak usia prasekolah?

\section{METODE}

Desain Penelitian. Tipe penelitian yang digunakan dalam penelitian ini adalah controlled field experiment, karena penelitian dilakukan dalam keadaan sewajarnya atau sehari-hari tanpa adanya kontrol ketat terhadap variabel sekunder (Seniati, Yulianto, \& Setiadi, 2009). Desain penelitian ini adalah randomized two-groups design, posttest only. Desain ini adalah desain yang sudah memenuhi syarat dilakukannya penelitian eksperimental karena dilakukannya randomisasi. Desain ini menggunakan prinsip method of difference, karena desain ini membuat dua kondisi yang berbeda pada dua kelompok penelitian (Seniati, Yulianto, \& Setiadi, 2009).

Partisipan Penelitian. Partisipan dalam penelitian ini adalah 76 anak murid TK usia 5-6 tahun yang dibagi menjadi 2 kelompok eksperimen. Teknik pengambilan sampel yang digunakan dalam penelitian ini adalah purposive sampling.

Alat Ukur Penelitian. Pada penelitian ini false memory diuji melalui proses rekognisi. Pada proses rekognisi partisipan diberi enam buah gambar dan pertanyaan netral untuk kelompok eksperimen 1, enam buah gambar dan pertanyaan misleading untuk kelompok eksperimen 2. Tidak ada perbedaan gambar yang diberikan untuk kedua kelompok. 
Gambar 1. Contoh Gambar Pertanyaan Kesatu

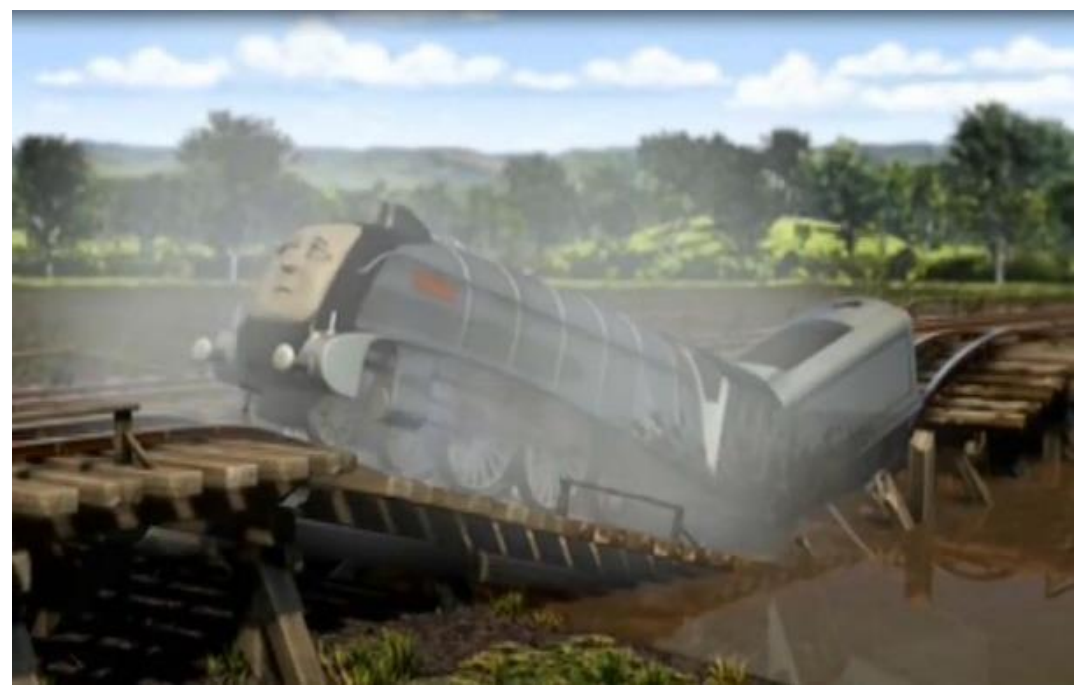

Gambar 2. Contoh Gambar Pertanyaan Kedua

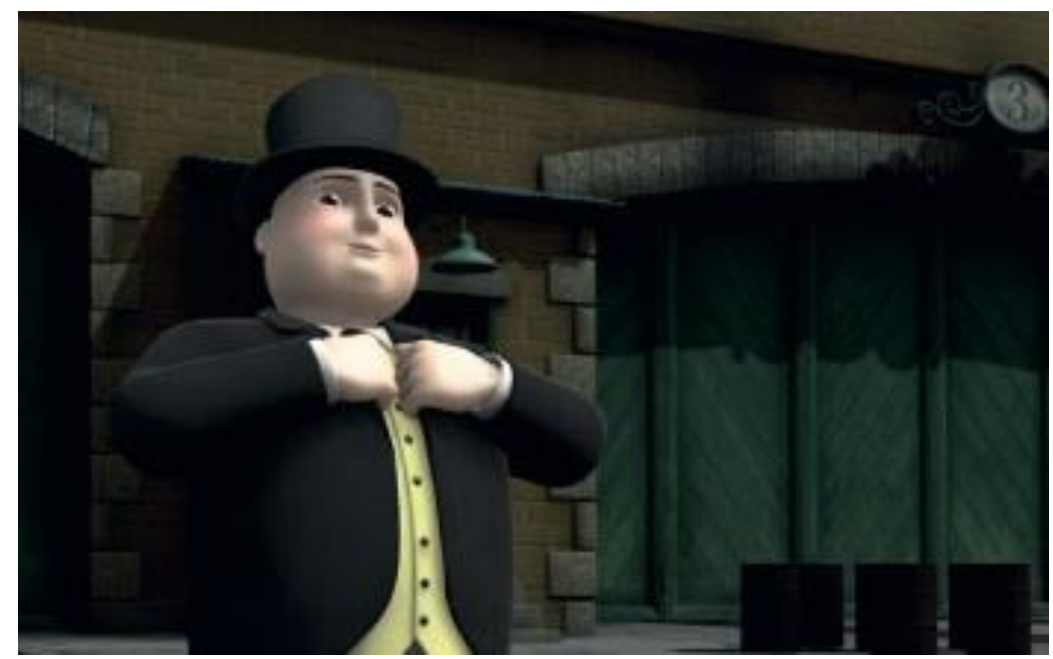

Gambar 3. Gambar Pertanyaan Ketiga

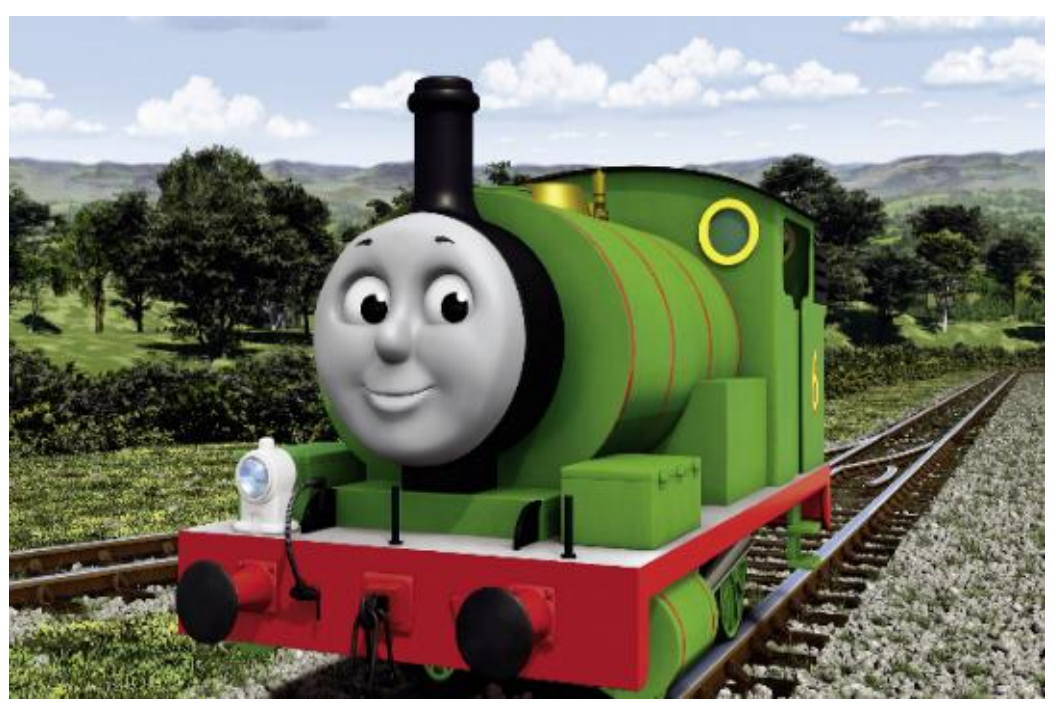


Sebelum pertanyaan dan gambar diberikan pada partisipan, partisipan diperlihatkan sebuah video Thomas and friends yang berdurasi dua menit. Pertanyaan dan gambar yang diberikan pada partisipan dibuat berdasarkan hal-hal yang tidak terjadi dalam jalan cerita dari video tersebut.

Tabel 1. Contoh Pertanyaan Netral

Pertanyaan Netral - Kelompok Eksperimen 1 (KE 1)

1 Apakah kereta ini yang jatuh di jembatan?

2 Apakah ada orang seperti ini dalam video tadi?

Tabel 2. Contoh Pertanyaan Misleading

Pertanyaan Misleading - Kelompok Eksperimen 2 (KE 2)

1. Kereta ini yang jatuh di jembatan kan?

2. Orang ini ada dalam video ya?

Prosedur Penelitian. Partisipan dibagi menjadi 2 kelompok, yaitu kempok eksperimen 1 (KE 1) dan kelompok eksperimen 2 (KE 2). Untuk memasukkan partisipan ke dalam kelompok eksperimen dilakukan randomisasi. Peneliti tidak mengontrol variabel intelegensi karena peneliti tidak memiliki data IQ partisipan. Setelah partisipan dibagi kedalam masing-masing kelompok eksperimen, masing-masing partisipan secara individual dipanggil bergantian untuk menemui para eksperimenter (3 eksperimenter di setiap kelompok) sesuai kelompoknya. Selanjutnya tiap-tiap eskperimenter memberitahu partisipan bahwa mereka akan diminta untuk menonton tayangan Thomas and friends, kemudian mereka akan diberikan pertanyaan terkait tayangan tersebut. Eksperimenter meminta partisipan untuk mengingat apa saja yang ada dalam video tersebut. Setelah tayangan selesai, eksperimenter memberikan gambar dan pertanyaan terkait tayangan tersebut. Gambar dan pertanyaan diberikan satu persatu secara berurutan. Partisipan diberi pertanyaan oleh eksperimenter sesuai kelompoknya. Untuk kelompok eksperimen 1 diberi jenis pertanyaan netral. Kelompok eksperimen 2 diberi jenis pertanyaan misleading.

Analisis Data. Untuk mengetahui apakah terdapat perbedaan antara pemberian jenis pertanyaan netral dan pertanyaan misleading terhadap munculnya false memory pada anak usia prasekolah, peneliti menggunakan teknik statistik chi-square dengan bantuan SPSS 20.0.

\section{HASIL}

Berdasarkan hasil pengambilan data, didapatkan 76 partisipan dari kedua TK tempat pengambilan data.

Tabel 3. Gambaran Partisipan Berdasarkan Jenis Kelamin

\begin{tabular}{llcc}
\hline & Jenis Kelamin & Frekuensi & Persentase \\
\hline \multirow{2}{*}{ KE 1} & Laki-laki & 22 & $57.9 \%$ \\
\cline { 2 - 4 } & Perempuan & 16 & $42.1 \%$ \\
\hline Total & & $\mathbf{3 8}$ & $\mathbf{1 0 0 \%}$ \\
\hline \multirow{2}{*}{ KE 2 } & Laki-laki & 19 & $50 \%$ \\
\cline { 2 - 4 } & Perempuan & 19 & $50 \%$ \\
\hline Total & & $\mathbf{3 8}$ & $\mathbf{1 0 0 \%}$ \\
\hline
\end{tabular}

Partisipan dibagi ke dalam dua kelompok berdasarkan jenis kelamin. Kelompok eksperimen 1 yang diberi jenis pertanyaan netral dan kelompok eksperimen 2 yang diberi pertanyaan misleading. Pada kelompok eksperimen 1 sebesar $57.9 \%$ partisipan adalah laki-laki dan $42.1 \%$ partisipan adalah perempuan. Sementara pada kelompok eksperimen 2 sebesar $50 \%$ adalah laki-laki dan $50 \%$ partisipan adalah perempuan.

Tabel 4. Gambaran Umum Partisipan Berdasarkan Usia

\begin{tabular}{llcc}
\hline Usia & & Frekuensi & Persentase \\
\hline \multirow{2}{*}{ KE 1} & $5 \mathrm{Thn}$ & 30 & $78.9 \%$ \\
& $6 \mathrm{Thn}$ & 8 & $21.1 \%$ \\
\hline \multirow{2}{*}{ Total } & & $\mathbf{3 8}$ & $\mathbf{1 0 0 \%}$ \\
\hline \multirow{2}{*}{ KE 2} & $5 \mathrm{Thn}$ & 28 & $73.7 \%$ \\
& $6 \mathrm{Thn}$ & 10 & $26.3 \%$ \\
\hline Total & & $\mathbf{3 8}$ & $\mathbf{1 0 0 \%}$ \\
\hline
\end{tabular}

Gambaran partisipan berdasarkan usia menunjukan pada kelompok eksperimen 1 sebesar 78.9\% adalah partisipan berusia 5 tahun dan $21.1 \%$ adalah pertisipan berusia 6 tahun. Sementara pada kelompok eksperimen 2 sebesar $73.7 \%$ adalah partisipan berusia 5 tahun dan sebesar $26.3 \%$ adalah partisipan berusia 6 tahun. 
Tabel 5. Hasil Uji Chi-square

\begin{tabular}{llll}
\hline & Value & df & $\begin{array}{c}\text { Asymp. Sig. } \\
\text { (2-sided) }\end{array}$ \\
\hline $\begin{array}{l}\text { Pearson } \\
\text { Chi-square }\end{array}$ & 11.647 & 5 & .040 \\
\hline $\begin{array}{l}\text { N of Valid } \\
\text { Cases }\end{array}$ & 74 & & \\
\hline
\end{tabular}

Hasil uji chi-square yang tertera pada tabel 5 menunjukan nilai pearson chi-square sebesar 11.647 dengan p-value sebesar 0.40. Hasil tersebut menunjukan terdapat perbedaan yang signifikan antara kelompok yang diberi pertanyaan netral dengan kelompok yang diberi pertanyaan misleading terhadap munculnya false memory. Hal ini dikarenakan nilai p-value lebih kecil dari alpha $(0.040<0.05)$ yang berarti signifikan. Sehingga dapat ditarik kesimpulan bahwa data mendukung hipotesis alternatif (Ha).

Tabel 6. Skor False Memory KE 1

\begin{tabular}{lcc}
\hline \multicolumn{3}{l}{ Kelompok Eksperimen 1 } \\
\hline Kategori & Frekuensi & Presentase \\
\hline Tidak Akurat & 21 & $55.3 \%$ \\
Cukup Akurat & 7 & $18.4 \%$ \\
Akurat & 9 & $23.7 \%$ \\
\hline Total & $\mathbf{3 8}$ & $\mathbf{1 0 0 \%}$ \\
\hline
\end{tabular}

Tabel 7. Skor False Memory KE 2

\begin{tabular}{lcc}
\hline \multicolumn{3}{l}{ Kelompok Eksperimen $\mathbf{2}$} \\
\hline \multicolumn{1}{c}{ Kategori } & Frekuensi & Presentase \\
\hline Tidak Akurat & 30 & $78.9 \%$ \\
Cukup Akurat & 3 & $7.9 \%$ \\
Akurat & 5 & $13.2 \%$ \\
\hline Total & $\mathbf{3 6}$ & $\mathbf{1 0 0 \%}$ \\
\hline
\end{tabular}

Tabel di atas menunjukan gambaran skor false memory partisipan pada masing-masing kelompok eksperimen berdasarkan tiga kategori, yaitu akurat, cukup akurat, tidak akurat (false memory). Kategori didapat dari norma skor partisipan kelompok eksperimen 1 yang diberi pertanyaan netral dan kelompok 2 yang diberi pertanyaan misleading. Pada kelompok eksperimen 1 yang diberi pertanyaan netral, 55.3\% partisipan masuk ke dalam kategori false memory. Sedangkan partisipan lainnya sebanyak 18.4\% masuk ke dalam kategori cukup akurat dan $23.7 \%$ sisanya masuk ke dalam kategori akurat. Berdasarkan hasil tersebut dapat dikatakan bahwa pada kelompok eksperimen 1 banyak partisipan yang mengalami false memory.

Pada kelompok eksperimen 2 yang diberi pertanyaan misleading, sebagian besar partisipan masuk dalam kategori false memory dengan persentase $78.9 \%$. Sedangkan partisipan sisanya sebanyak $7.9 \%$ masuk dalam kategori cukup akurat dan $13.2 \%$ masuk dalam kategori akurat. Berdasarkan hasil tersebut terlihat jumlah partisipan yang mengalami false memory pada kelompok eksperimen 2 lebih banyak dari kelompok eksperimen 1 .

Tabel 8. Mean Kelompok

\begin{tabular}{llcc}
\hline & & $\begin{array}{c}\text { Kelompok } \\
\text { Eksperimen 1 }\end{array}$ & $\begin{array}{c}\text { Kelompok } \\
\text { Eksperimen 2 }\end{array}$ \\
\hline N & Valid & 38 & 36 \\
& Missing & 38 & 40 \\
Mean & & 1.74 & .64 \\
\hline
\end{tabular}

Pada tabel 8 menampilkan hasil perhitungan nilai mean pada kelompok eksperimen 1 dengan hasil sebesar 1,74. Pada kelompok eksperimen 2 nilai mean yang didapatkan sebesar 0,64. Berdasarkan nilai mean pada masing-masing kelompok, terlihat nilai kelompok eksperimen 1 lebih besar dari kelompok eksperimen 2. Lebih rendahnya nilai mean pada kelompok eksperimen 2 mengartikan bahwa partisipan pada kelompok tersebut banyak yang salah dalam menjawab pertanyaan. Banyaknya partisipan yang salah dalam menjawab pertanyaan menandakan false memory lebih banyak terjadi pada kelompok eksperimen 2 yang diberi pertanyaan misleading. 


\section{SIMPULAN}

Berdasarkan hasil analisis yang telah dilakukan peneliti dan dijelaskan pada bagian sebelumnya, peneliti mengambil kesimpulan bahwa terdapat perbedaan yang singnifikan antara jenis pertanyaan netral dan misleading terhadap munculnya false memory pada anak usia pra sekolah.

Berdasarkan hasil perhitungan statistik, menunjukan bahwa ada perbedaan yang signifikan antara pemberian jenis pertanyaan netral dan pertanyaan misleading terhadap munculnya false memory pada 'anak usia prasekolah. Hasil tersebut membuktikan bahwa anak usia prasekolah yang diberi pertanyaan misleading mengalami false memory lebih banyak dibanding anak yang diberi pertanyaan netral. Hasil penelitian ini sejalan dengan penelitian yang dilakukan oleh Ceci \& bruck (1995). Ceci \& Bruck (1995), menemukan bahwa anak-anak yang diberikan pertanyaan misleading secara berulang-ulang, sebanyak $60 \%$ memberikan laporan yang salah atas kejadian yang dialaminya.

Bila dianalisa berdasarkan tahap perkembangan memori, anak usia pra sekolah mulai meningkatkan perhatian, kecepatan pengolahan informasi, dan mulai membentuk memori jangka panjang (Papalia \& Feldman, 2014). Hal tersebut membuat kemampuan mengingat anak-anak usia prasekolah tidak sebaik orang yang lebih dewasa. Sehingga ingatan anak-anak rentan mengalami kesalahan dalam mengingat. Rentannya ingatan anak-anak dalam mengalami kesalahan menjadi salah satu faktor munculnya false memory (Ghetti \& Alexander, 2004).

Selain ingatan anak-anak yang dalam perkembangan rentan mengalami kesalahan, ada faktor lain yang mempengaruhi ingatan anak, yaitu pemberian petunjuk atau isyarat. Santrock (2010), menyatakan pemberian petunjuk atau isyarat pada anak-anak dapat membuat anak mengingat informasi dengan baik, apabila pentujuk atau isyarat yang diberikan tepat dan sesuai dengan informasi yang diingat anak.
Pemberian petunjuk atau isyarat yang tidak sesuai dengan informasi yang diingat anak-anak, bisa menyebabkan anak mengalami distorsi dalam ingatannya (Scharter, 2014).

Ketika memberi petunjuk atau isyarat yang salah, sama halnya dengan mensugesti anak pada informasi yang salah. Pemberian pertanyaan misleading pada informasi yang salah merupakan salah satu contoh pemberian petunjuk atau isyarat yang bisa mendistori ingatan anak-anak. Ketika anak diberi pertanyaan misleading, maka petunjuk atau isyarat yang ada pada pertanyaan tersebut akan masuk dalam memori anak (Ceci \& Bruck, 1995). Sehingga anak-anak yang diberi jenis pertanyaan misleading pada penelitian ini lebih banyak mengalami false memory.

Meskipun jenis pertanyaan misleading lebih banyak memunculkan false memory, bila melihat hasil perhitungan, terdapat $42.1 \%$ partisipan pada kelompok netral tidak bisa menjawab seluruh pertanyaan dengan benar. Pada kelompok misleading sebanyak $68.4 \%$ partisipan tidak bisa menjawab seluruh jawaban dengan benar. Data tersebut membuktikan bahwa false memory muncul pada kelompok yang diberi jenis pertanyaan netral. Hal ini membuktikan bahwa kedua jenis pertanyaan dapat memunculkan false memory pada anak usia prasekolah. Tetapi penggunaan jenis pertanyaan misleading membuat false memory lebih banyak muncul atau dialami oleh anak usia prasekolah.

Hasil tersebut sejalan dengan penelitian yang dilakukan oleh Cassel, Roebers, dan Bjorklund (1996). Pada penelitian tersebut Cassel dkk (1996), melakukan eksperimen pada partisipan anak-anak TK, SD kelas 2, SD kelas 4, dan orang dewasa. Hasilnya, partisipan orang dewasa dan anak-anak yang lebih tua (anak-anak SD), memiliki ingatan yang lebih akurat dibanding anak-anak TK. Partisipan anak-anak TK lebih banyak menjawab salah ketika diberikan pertanyaan misleading dan pertanyaan netral.

Pada penelitian ini juga ditemukan fakta bahwa teknik rekognisi masih bisa memunculkan false memory pada anak prasekolah. Teknik rekognisi pada anak-anak usia prasekolah di masing-masing kelompok eksperimen. Bila hasil 
penelitian ini dikaitkan pada teori perkembangan kognitif Piaget (dalam Santrock, 2010), anakanak usia prasekolah memasuki tahap perkembangan praopersional. Salah satu ciri khas tahap praoperasional adalah adanya sentrasi (centration). Sentrasi membuat anak-anak cenderung fokus pada salah satu aspek dari sebuah situasi dan cenderung melalaikan yang lain. Salah satu bentuk sentrasi adalah egosentris.

Anak yang mengalami egosentris mengalami kesulitan memisahkan kenyataan yang ia alami dengan apa yang ada dalam pikirannya (Papalia \& Feldman, 2014). Pada eksperimen ini, egosentris mempengaruhi anak ketika ia melihat video animasi Thomas and friends lalu melihat gambar saat proses rekognisi. Saat rekognisi anak-anak diberikan gambargambar yang tidak ada dalam video Thomas and friends. Akibatnya, anak-anak mengalami kebingungan memisahkan mana informasi yang mereka lihat saat menonton video dan yang tidak mereka lihat. Sehingga anak yang tidak diarahkan dan diberi pertanyaan misleading pada informasi yang salah pun juga bisa salah dalam mengingat karena adanya egosentris.

Meskipun hasil dari penelitian ini sejalan dengan penelitian-penelitian sebelumnya, peneliti merasa ada beberapa hal yang menjadi kelemahan penelitian ini. Pertama, jumlah partisipan yang menjadi sampel penelitian sedikit. Jumlah partisipan pada penelitian ini hanya 76 partisipan, di mana masing-masing kelompok terdapat 36 partisipan. Penyebab dari sedikitnya jumlah partisipan adalah tidak semua TK yang peneliti datangi memberikan izin untuk peneliti melakukan penelitian. Banyaknya partsipan tentunya akan semakin membuat hasil penelitian representatif dengan populasi subjek penelitian.

Kedua, jumlah eksperimenter yang sedikit. Pada penelitian ini hanya terdapat enam eksperimenter. Jumlah eksperimenter yang sedikit membuat waktu eksperimen menjadi lebih lama, hal ini disebakan penelitian eksperimen ini dilakukan secara individual. Sehingga jumlah eksperimenter yang banyak akan membuat semakin banyak partsipan yang langsung mengikuti jalannya eksperimen dan waktu yang dibutuhkan akan lebih sedikit.

Peneliti menuliskan beberapa saran yang dapat digunakan untuk perkembangan penelitian pada variabel false memory khususnya pada anak usia prasekolah.

1. Bagi peneliti lain yang tertarik untuk mengembangkan penelitian false memory, bisa mengujinya dengan perbedaan teknik retrieval (recall dan rekognisi). Hal ini menjadi menarik karena secara teori dan dari hasil penelitian sebelumnya recall merupakan teknik retrieval yang lebih susah dibanding rekognisi.

2. Bagi peneliti lain yang tertarik untuk meneliti false memory bisa melakukan penelitian dengan beberapa kelompok usia partisipan. Seperti membandingkan antara orang dewasa dengan anak-anak usia prasekolah atau anakanak usia prasekolah dengan anak-anak yang usianya lebih tua. Hal ini menarik karena secara teori kemampuan memori meningkat seiring bertambahnya usia.

3. Bagi peneliti lain yang tertarik untuk meneliti false memory juga bisa mengaitkannya dengan fokus ingatan dari laporan para partisipan. Hal ini menarik karena secara teori anak usia prasekolah fokus pada detil-detil informasi yang diingat. Sementara orang dewasa lebih kepada intisari dari informasi yang ia ingat.

4. Bagi peneliti ataupun pakar psikologi khususnya psikologi forensik dapat mengembangkan hasil penelitian ini untuk membuat suatu metode wawancara yang dikhususkan untuk menggali infromasi atau keterangan dari anak (khususnya anak usia prasekolah) yang tidak menggunakan pertanyaan-pertanyaan yang mengarahkan pada suatu jawaban (leading atau misleading).

Berdasarkan hasil penelitian ini, peneliti menuliskan beberapa saran yang dapat digunakan oleh masyarakat ataupun pihak-pihak yang bersinggungan dengan anak-anak usia prasekolah.

1. Berdasarkan hasil penelitian, penggunaan pertanyaan netral maupun jenis pertanyaan 
misleading sama-sama memunculkan false memory. Hal ini membuktikan bahwa ingatan anak-anak sangat rentan mengalami kesalahan. Oleh sebabnya, peneliti menyarankan ketika anak dimintai keterangan atau memberikan kesaksian, perlu metode penggalian informasi yang sesuai standar keilmuan psikologi forensik khususnya dalam hal wawancara atau penggalian infromasi. Serta penggalian informasi dilakukan oleh ahli dalam bidang psikologi forensik.

2. Hasil penelitian ini juga dapat digunakan untuk mengedukasi para orang tua atau masyarakat pada umumnya tentang false memory. Berdasarkan hasil penelitian ini juga dapat dikatakan bahwa keterangan yang disampaikan anak usia prasekolah tidak sepenuhnya benar. Sehingga anggapan bahwa ucapan anak-anak selalu benar karena anak tidak pernah berbohong tidak sepenuhnya benar.

\section{DAFTAR PUSTAKA}

Bruck, M., \& Ceci, S. J. (1999). The suggestibility of children's memory. Annual Review of Psychology, 50, 419439.

Bruck, M., Ceci. S. J., Francoeur, E., \& Renick A. (1995). Anatomically detailed dolls do not facilitate preschooler reports of a pediatric examination involving genital touching. Journal of Experimental Psychology, Applied 1, 95-109.

Cassel, W. S., Roebers, C., \& Bjorklund, D. F. (1996). Developmental patterns of eyewitness responses to repeated and increasingly suggestive questions. Journal of Experimental Child Psychology, 61, 116-133.

Ceci S. J., \& Bruck, M. (1993). The suggestibility of the child witness: A historical review and synthesis. Psychology Bulletin, 113, 403-39.

Ceci, S. J., \& Bruck, M. (1995). Jeopardy in the courtroom: A scientific analysis of children's testimony. Washington DC: American Psychological Association.
Ghetti, S., \& Alexander, K. W. (2004). "If it happened, I would remember it": Strategic use of event memorability in the rejection of false autobiographical events. Child Development, $75,542-561$.

Loftus, E. F. (2003). Award for distinguished scientific applications of psychology. American Psychologist, 11, 864-873.

Papalia, D. E., \& Feldman, R. T. (2014). Experience human development (12th Ed.). New York: Mc-Hill Graw.

Santrock, J. (2010). Life-span development (13th Ed.). New York: Mc-Hill Graw.

Santrock, J. (2010b). Child development: An introduction (13th Ed.). New York: McHill Graw.

Seniati, L., Yulianto, A., \& Setiadi, B. N. (2009). Psikologi eskperimen. Jakarta: PT Indeks.

Smith, E. E., \& Kosslyn, S. M. (2014). Psikologi kognitif: Pikiran dan otak. Yogyakarta: Pustaka Pelajar.

Sophian, C., Wood, A., \& Vong, K. I. (1995). Making numbers count: The early development of numerical inferences. Development Psychology, 31, 263-273.

Stewart, C. J., \& Cash, W. B. (2012). Interviu: Prinsip dan praktik (13th Ed.). Jakarta: Salemba Humanika. 